\title{
Recent peat slide in Co. Antrim extends the known range of weak basal peat across Ireland
}

\author{
Alan P. Dykes * \\ BSc(Hons), PhD, FRGS, FHEA, FGS, CGeol, Associate Professor at Kingston University, Kingston upon Thames, UK
} ORCID: 0000-0003-0327-0498

\author{
* Corresponding author: \\ Centre for Engineering, Environment and Society Research, School of Engineering and the Environment, Kingston \\ University, Penrhyn Road, Kingston upon Thames, KT1 2EE, UK, Tel.: +44 (0)208 417 7018, Email: \\ a.p.dykes@kingston.ac.uk
} 6399 words (excluding Figure captions and Tables), 10 Figures, 2 Tables

\begin{abstract}
Peat instability and failure became an important topic of study following a series of damaging landslides in 2003. A peat slide in August 2014 at Croaghan, in the Orra Mountains of Co. Antrim, Northern Ireland, provided the first opportunity to directly compare estimates of peat shear strength from Direct Simple Shear (DSS) and tensile strength (TS) testing. Physical properties of peat from throughout the depth profile were obtained to provide reference characteristics for the strength test results, and to facilitate comparisons with results from locations where detailed botanical compositions have been analysed.
\end{abstract}

Both methods showed that the basal peat at the study site had a shear strength much lower than $6 \mathrm{kPa}$. The physical properties are the same as at sites $150 \mathrm{~km}$ further southwest, so the composition of the peat at the study site is inferred to be dominated by sedges (particularly Eriophorum vaginatum) with some heathers (Ericacae) and mosses (including Sphagnum). The weak basal layer appears to be similarly lacking fibres, which allowed failure to occur in response to adverse water pressures arising from extreme rainfall. Basal shear strength of $<5 \mathrm{kPa}$ is a reasonable starting assumption for planned engineering works on intact blanket peat in Ireland. 
Key words Fabric/structure of soils, Landslides, Strength \& testing of materials

\author{
Notation \\ F factor of safety \\ $\mathrm{K}_{\text {sat }} \quad$ saturated hydraulic conductivity \\ p'c preconsolidation stress \\ $\mathrm{S}_{\mathrm{u}} \quad$ undrained shear strength \\ $\sigma_{\mathrm{v}} \quad$ consolidation stress \\ $\tau_{\mathrm{h}-\max } \quad$ peak horizontal shear stress \\ $\phi \quad$ friction angle
}

\title{
1. Introduction
}

In recent years, particularly since 2003 when extreme rainfall events and windfarm projects caused several major landslide events, instability and failure of blanket peat has become a topic of significant interest in the UK and Ireland because of the dual concerns of (i) landslide hazards to the public associated with increasingly likely high intensity rainfall events (Moore et al. 2006; Dykes \& Warburton 2007a, 2008a; Winter et al. 2009) and (ii) environmental impacts of peat failures arising from the construction of access roads or tracks on peatlands, most commonly associated with onshore windfarms (Lindsay and Bragg 2005; Dykes and Jennings 2011; Long et al. 2011). Many of the key issues have been identified, discussed and investigated in recent years, including hydrological controls (Warburton et al. 2004), anthropogenic factors (Dykes 2008a; 2012; Long et al. 2011), topographic and underlying geological factors (Dykes and Warburton 2007a, 2008b) and geotechnical characteristics of the peat (e.g. Long 2005; Zhang and O’Kelly 2014). Under the latter category, an ongoing issue has been to establish a reliable means of obtaining a realistic and applicable measure of the strength of the peat for use in engineering analyses relating to landslide risk assessments (Boylan and Long 2014). The likely importance of botanical controls on the geotechnical characteristics was highlighted by Hobbs (1986) and Bell (2000) and reiterated by Dykes and Kirk (2006) and Dykes (2008b). However, the development of methods to estimate the peat strength such as use of full-flow penetrometers (Boylan et al. 2011) or measurement of tensile strength (Dykes 2008c) did not 
address the botanical content. New targeted research into botanical factors was initiated by Foteu Madio (2013; also Foteu Madio et al. 2012), providing the first base-line indication of peat characteristics associated with particular botanical composition(s).

This paper arose from an opportunity to directly compare two different approaches to the measurement of peat strength using a recent landslide in upland blanket bog typical of recent peat failure contexts in Ireland. A recent landslide provides the best means of obtaining a comprehensive set of good quality samples of intact peat for laboratory testing, that can be related to a failure occurrence and obtained without the use of machinery (a condition of site access in this case). A further advantage of this study is that it extends the geographical range of such investigations, enabling inferences to be made about the general applicability in Ireland of results obtained. The primary aim of this paper is therefore to establish whether Direct Simple Shear (DSS) and tensile strength tests give comparable results indicating the shear strength of basal peat to be less than 5 kPa (i.e. typical of Irish peat failures: Dykes and Jennings 2011; Dykes 2012). A secondary hypothesis is that the peat characteristics at the study site in Co. Antrim are consistent with the upland blanket peat in NW Ireland (Counties Sligo, Leitrim and Cavan), indicating broadly the same botanical composition (c.f. Foteu Madio and Dykes 2018). The landslide can then be explained in terms of peat characteristics (i.e. linking back to an inferred botanical composition) and a rainfall trigger.

\section{Study Site}

\subsection{Location and context}

This research used a recent natural peat slide at Black Hill, 1 km south of Croaghan Mountain, in the Orra Mountains of Co. Antrim in Northern Ireland (Fig. 1). It occurred during heavy rainfall on Saturday 2 or Sunday 3 August 2014 and was widely reported in the UK media on account of the runout flow having been filmed and broadcast on television news bulletins (Best 2014). The head of the landslide is located at 6¹4’52.2”W, 5506’25.6”N (Irish Grid coordinates D 11878, 30280) at an altitude of around $340 \mathrm{~m}$, and the entire landslide lies within the Slieveanorra and Croaghan ASSI (Area of Special Scientific Interest) (DAERA 2015), designated on account of its largely intact blanket bog. Slopes are gentle in the area immediately surrounding the landslide, locally $12^{\circ}$ above the upper eastern side of the landslide source area 
but mostly less than around $6-7^{\circ}$. The vegetation at the site is typical of the ASSI citation, i.e. 'dominated by Heather Calluna vulgaris, with Cross-leaved Heath Erica tetralix, Hare’s-tail Cottongrass Eriophorum vaginatum, Crowberry Empetrum nigrum and Bilberry Vaccinium myrtillus growing over a mixed moss and liverwort mat' (DAERA 2015, p.1 of the Declaration of ASSI). The entire area was burnt in 2010 (Mr D. McAleese, farm worker, pers. comm. 2015) which may explain this vegetation assemblage typical of slightly drier peat. Around half-way down the landslide source area and on either side of it there is a slightly steeper slope on the surface of the peat associated with a much denser cover of grasses rather than the heather that dominates elsewhere. According to the local gamekeeper, this part of the slope was always much drier than surrounding areas (Mr D. Anderson, pers. comm. 2015; Fig. 1). The peat downslope of this zone is significantly thinner than further up, typically between $1.0 \mathrm{~m}$ and $1.5 \mathrm{~m}$ (Fig. 2) and, like the flatter area above the head of the slide, was always much wetter than the main slope above from which the peat has moved according to Mr Anderson. Aerial images from Google Earth (image dates 15 Jul. 2001, 25 Aug. 2002, 23 Jul. 2011 and 4 Sep. 2015) show some ditches draining into the surface stream that runs down the gentle depression immediately west of the landslide (Fig. 1). These were confirmed by additional field inspection in September 2017.

\section{$<$ FIGURE $1>$}

Figure 1. (A) View of the landslide (dark area upper centre) from the southeast indicating slope and drainage features mentioned in the text. A natural drainage line can be seen to the left (west) of the lower source area. (B) View towards the head of the landslide from further upslope, showing the natural drainage line that conveyed runoff towards the failed area of slope. The surface channel ends around $10 \mathrm{~m}$ upslope from the source area and is assumed to drain into one or more subsurface peat pipes. (C) Location of the peat slide in Northern Ireland. Grey shading indicates peatlands (after Hammond 1979).

\section{$<$ FIGURE $2>$}

Figure 2. Outline of the peat slide source area showing (i) failure surface gradient, (ii) location of the sampling site, (iii) approximate line of the stream course shown in Fig. 1B, and (iv) depths of undisturbed peat (metres) as measured at the location of the bottom-centre of each scaled rectangle. Coordinates refer to the Irish Grid: Eastings increase from D311800 m, Northings increase from D430090 m. 


\subsection{Landslide description}

The landslide source area is around $195 \mathrm{~m}$ long from the head to the downslope limit of an identifiable scar. Around $15,000 \mathrm{~m}^{3}$ of blanket peat, corresponding to 15,000 tonnes of peat that is at least $90 \%$ water by composition, were displaced from an area of approximately $7500 \mathrm{~m}^{2}$ of the slope. A large proportion of the peat that moved was retained on the slope immediately below the source area. This quantity of retained peat is difficult to estimate because the deposit loses mass continually as it dries due to exposure, but large parts of the site remained too wet to walk on at the time of the site visit in 2015. Mr Anderson (pers. comm. 2015) reported that it took $1 \frac{1 / 2}{2}$ hours for the peat to advance the $400 \mathrm{~m}$ to the road from the time that movement was first seen on the hill, and suggested that 'around 1000 tonnes of peat' were carried as far as a bridge a mile ( 1.6 km) down the valley by the associated floodwater.

The mineral substrate is characterised by fragments of weathered bedrock, up to around a metre in size, set in a thin surficial layer of silty sand. The topographic surface of the substrate is broadly planar near the head, but with locally steeper bands like 'steps' (up to $1 \mathrm{~m}$ wide) across the surface further downslope. DAERA (2015) record the geology as comprising 'predominantly metamorphosed mudstones and sandstones of the Southern Highland Group', of Neoproterozoic age (>540 million years old: NERC 2017). In some places the peat has grown directly on the surfaces of stones but mostly it merges into the sand within the space of just a few millimetres. In places there are also remains of tree trunks and large branches, in one case $1 \mathrm{~m}$ long and $0.2 \mathrm{~m}$ in diameter, within the basal peat, remnants of the forest that preceded the spread and accumulation of the peat across the weathered land surface more than 5000 years ago (DAERA 2015). Most of the upper scar displayed a shear surface generally 10-20 mm above the level of most of the stones and sand and the large woody fragments, hence the landslide is classified as a peat slide (Dykes and Warburton 2007b).

\subsection{Occurrence of the landslide: hydrological factors}

Peat landslides like this have occurred regularly (though infrequently) throughout Ireland over the last century, but may become slightly more common as the frequency of 'extreme' rainfall events increases. Several recurring characteristics indicate specific risk factors (Dykes and Kirk 2001; Dykes 2008a; Long et al. 2011). Of these factors, deep peat along drainage lines, mechanical disturbance of the peat mass by people and possibly a history of burning (although this is less certain) are present at this site. In particular, peat 
slides commonly occur when peatlands have experienced a long period of warm, dry weather in summer and then there is an extremely heavy rainfall event (Dykes 2008a).

The western side of the upper half of the landslide source area (left side when looking upslope: Fig. 1A) corresponds with a gentle 'hollow' form in the mountainside, i.e. a shallow depression within which the peat is deeper ( $>2.6 \mathrm{~m}$, estimated 2.6-3.0 m) but where rainwater would inevitably be concentrated, either at the surface or at some level within the peat. To the east side of the upper half, the peat is slightly less deep (typically 2.0-2.5 m: Fig. 2) but much steeper - up to $12^{\circ}$. However, there is a prevailing gradient of $6.5^{\circ}$ throughout the source area which is moderately steep for such deep peat. A natural surface drainage channel feeds water towards the head of the landslide source area (Figs. 1B, 2) but the channel peters out around 10 m upslope of the landslide head where the flow disappears underground. This is evidence of the likelihood of significant peat pipes within the deeper peat on the slopes around the upper part of the source area.

UK Met Office data show that overall, Northern Ireland was generally warmer and sunnier than both 30-year reference period averages throughout June and July 2014 and August was cooler and wetter (Table 1), but monthly rainfall totals were all within normal ranges (Met Office 2017a,b). However, the storm of 2-3 August was not only a major event, it was probably the first significant rainfall onto dry and cracked peat after two very warm months. Figure 3 shows the effect of this highly localised event on the regional data, including a very sharp rise in the 15-day antecedent rainfall on 2 August. This latter parameter was used to define landslide thresholds by Lumb (1975), Pasuto and Silvano (1998) and Bell and Maud (2000) but is presented here as an indicative illustration only of a possible failure threshold condition. Rainfall totals at the landslide site are unknown but Best (2014) suggested that there was ‘up to $50 \mathrm{~mm}$ within a few hours', reporting Met Office figures of $49.8 \mathrm{~mm}$ at Ballypatrick Forest Park near Ballycastle (156 m altitude), 41.8 mm at Altnahinch Filters near Dunloy (213 m), and $32.4 \mathrm{~mm}$ at Killylane near Armoy (250 m). The latter location is nearest to the landslide site, around $6 \mathrm{~km}$ to the northwest and $90 \mathrm{~m}$ lower elevation, but the rainfall was highly localised and variable throughout the region and may have been considerably higher at the study site. 
Rainwater is more easily able to reach the base of the peat - often by means of peat pipes below the depth of surface cracking - by entering cracks formed by drying of the surface layer (Holden and Burt 2002, 2003). Indeed, surface cracks were observed to have opened up in the peat in the days immediately prior to the landslide in late July 2014, although they only affected the living root layer. Table 1 shows higher temperatures and lower rainfall than the average during June and July. Mr Anderson (pers. comm. 2015) indicated that these cracks were typically '6-9 inches' (around 150-225 mm) wide at the top and '3-4 inches' (75-100 mm) deep, thus affording significant direct access to the catotelm peat for rainwater. The hydrological effects of such rainwater for peat slope failure were discussed by Warburton et al. (2004).

Table 1. Selected regional climate data for Northern Ireland. ‘Anom.’ = anomalies from the 1961-1990 / $1981-2010$ mean values. Source: Met Office (2017a).

\begin{tabular}{|c|c|c|c|c|c|c|c|c|}
\hline Month in & \multicolumn{2}{|c|}{ Maximum temperature } & \multicolumn{2}{|c|}{ Mean temperature } & \multicolumn{2}{|c|}{ Sunshine } & \multicolumn{2}{|c|}{ Rainfall } \\
\hline 2014 & Actual $\left({ }^{\circ} \mathrm{C}\right)$ & Anom. $\left({ }^{\circ} \mathrm{C}\right)$ & Actual $\left({ }^{\circ} \mathrm{C}\right)$ & Anom. $\left({ }^{\circ} \mathrm{C}\right)$ & Actual (h) & Anom. (\%) & Actual (mm) & Anom. (\%) \\
\hline June & 17.9 & $1.3 / 1.1$ & 13.8 & $1.4 / 1.0$ & 170 & $107 / 113$ & 57 & $77 / 74$ \\
\hline July & 20.1 & $2.2 / 1.6$ & 15.7 & $1.7 / 1.1$ & 157 & 112 / 112 & 73 & $102 / 89$ \\
\hline August & 17.1 & $-0.5 /-1.0$ & 13.4 & $-0.4 /-0.9$ & 153 & $113 / 113$ & 136 & $142 / 139$ \\
\hline
\end{tabular}

\section{$<$ FIGURE $3>$}

Figure 3. Regional daily precipitation for Northern Ireland for 2014 (black line) and the corresponding 15-day antecedent precipitation (grey line). Source: Met Office (2017a, after Alexander and Jones 2001). The occurrence of the landslide is indicated by the arrow.

\section{Methods}

\subsection{Field investigations}

The peat slide was examined during 1-5 August 2015, then again during 10-12 September 2017. Following the recording of initial observations and photographic evidence, the source area was mapped using a handheld GPS (Dykes 2008d). The thickness of the in-situ peat surrounding the landslide was determined by 
probing on a regular $10 \mathrm{~m}$ grid with a $2.6 \mathrm{~m}$ long metal rod. One location on the eastern margin of the upper scar (6¹4’51.1’W, 5506’24.9’ N, Irish Grid coordinates D 11898, 30257) was found to be suitable for the preparation of a clean vertical profile through the full depth of the peat in that there was little peat debris in front of the profile and no visible disturbance to the in situ peat behind the face (Fig. 4). Safety was ensured by having wide open access to the prepared profile from within the evacuated source area of the landslide and making regular careful inspections of the peat face during the work. Ideally at least one further profile would have been examined to provide replication and, thus, a means of quantifying parameter uncertainty due to spatial variability of the peat. Unfortunately there was no safe or feasible option for the creation and investigation of a second profile. A detailed description of the prepared profile was recorded, according to the von Post classification scheme (von Post, 1922, as presented by Landva and Pheeney, 1980, and Hobbs, 1986), then a standard hand-held four-blade shear vane (e.g. Geonor H-60) was used to obtain measurements of the 'field vane strength' (FVS) of the peat at discrete depths through the intact peat $0.5 \mathrm{~m}$ behind the prepared profile.

The sampling strategy was intended to provide depth-related data for a range of different physical and geotechnical properties whilst maximising the number of samples to ensure sufficient successful test results and support a series of experiments. Depth intervals were adjusted from equal spacing to accommodate visual layer boundaries in the prepared vertical profile. Fig. 5 shows the types of samples obtained and reported in this paper, and where in the profile they came from. The drying and oxidation effects of exposure of a peat face by a landslide have not been discernible in visible characteristics or laboratory test results from more than a few tens of millimetres back into the in-situ peat, even after several years (A P Dykes, unpublished data). Likewise, the effects of burning of blanket peat do not appear to affect the peat characteristics below a few tens of millimetres depth (Foteu Madio 2013). Initial site inspections as soon as possible after failure are needed to identify features pertaining to the failure occurrence that may degrade or become buried or otherwise obscured by subsequent degradation of exposed peat margins. However, as long as a clean profile can be cut through the peat 0.1-0.2 m back from an exposed face, then the properties of the peat are likely to be little different from the time of failure and well within the range of undisturbed natural variability. 


\subsection{Laboratory testing}

Peat humification was determined for the peat profile in the field and laboratory samples used for strength testing, using the von Post 'squeeze’ test (Hobbs, 1986; Carlsten, 1993; Bell, 2000). The small 50 mm long $\times$ $50 \mathrm{~mm}$ diameter cores of intact peat, horizontally aligned, were used to determine the dry, field-wet and saturated bulk densities, field-wet and saturated water contents (using oven-drying at $105^{\circ} \mathrm{C}$, e.g. O’Kelly 2017; Li et al. 2018), ash contents after ignition at $550^{\circ} \mathrm{C}$ for 24 hours (Skempton and Petley 1970; Andrejko et al. 1983; Jarret 1983; Hobbs 1986) and the (horizontal) saturated hydraulic conductivity using a 'constant head' method. This range of properties, together with the fibre content (not needed as tensile strength was measured directly), represents a generally accepted standard set of peat properties that can be used to infer other engineering properties (O’Kelly 2016), although some of the correlations may not hold for highly humified Irish blanket bog peat (Dykes 2008b).

The tensile strength (TS) blocks, each approximately $120 \times 120 \times 80 \mathrm{~mm}$, were cut from the peat profile so that the applied tensile stresses acted horizontally with respect to the in situ alignment of the peat. The tensile strength measurements were obtained by testing samples cut to $100 \times 100 \times \sim 60 \mathrm{~mm}$ using the equipment and methodology described by Dykes (2008d), with pre- and post-test water contents and full von Post classifications also being determined.

The Direct Simple Shear (DSS) blocks, the same size as for TS (above), were extracted so that the applied shear stresses acted horizontally. Four oedometer tests were done on $76 \mathrm{~mm}$ diameter $\times 19 \mathrm{~mm}$ high specimens cut from the blocks, to determine the degree of overconsolidation of the peat according to BS1377 (1990) with loads being maintained for 24 hours. The load steps used were chosen so as to try to determine the preconsolidation stress as closely as possible. Six DSS tests were then carried out on samples $79.5 \mathrm{~mm}$ diameter $\times 19 \mathrm{~mm}$ high, cut from the blocks, using a Geonor H12 DSS apparatus (Bjerrum and Landva 1966) following procedures used by the Norwegian Geotechnical Institute (Andresen et al. 1979). In summary these involved (Long 2016): (i) consolidating test samples in a single step (due to the very low stresses involved) to the required consolidation stress ( $\left.\sigma^{\prime} v\right)$ by loading dead weights onto the lever arm and then leaving overnight.; (ii) shearing each sample by applying a horizontal shear stress to the top of the sample at a shear strain rate of approximately $4 \%$ shear strain per hour, occasionally adjusting the vertical 
stress to maintain the constant height of the sample and, thus, constant volume conditions. The undrained shear strength $\left(\mathrm{s}_{\mathrm{u}}\right)$ is taken to be equal to the peak horizontal shear stress $\left(\tau_{\mathrm{h}-\mathrm{max}}\right)$ attained during shearing or alternatively the shear stress measured at $15 \%$ shear strain, whichever occurs first.

\section{$<$ FIGURE $4>$}

Figure 4. The upper eastern margin of the source area in August 2015 immediately prior to sampling, showing the sampling site and details of the failure surface. Some residual peat has been eroded away, but much of the failure surface was just high enough above the peat-mineral interface to override the large stones (white appearance in this photograph) and remains of ancient trees. The visible piece of wood (bottom centre) is just over $1 \mathrm{~m}$ long and $200 \mathrm{~mm}$ in diameter.

$<$ FIGURE 5>

Figure 5. Representation of the peat profile stratigraphy and sampling strategy at the peat face identified in Fig. 4. Brief descriptions of the peat layers are provided in Table 2 . WC $=50 \mathrm{~mm}$ dia. $\times 50 \mathrm{~mm}$ long cores for physical properties (2 from each depth), TS = blocks for tensile strength (3 from each depth), DSS = blocks for direct simple shear tests (3 from each depth).

\section{Results}

\subsection{Peat profile descriptions}

The burning of the vegetation in around 2010 appears to have had little effect on the peat below the layer of living roots, i.e. the top 50-100 mm. Below this layer there is little variation in the visible character of the peat (Table 2). The density of discrete plant fragments throughout the peat mass and the sizes of those remains generally decrease downwards through the peat while the state of decomposition (humification) increases (Fig. 7a). However, all layers below $70 \mathrm{~mm}$ depth contained occasional zones of woody/shrub remains $\left(\mathrm{V}_{2}-\mathrm{V}_{3}\right.$ on the Von Post scale, where $\mathrm{V}$ represents the combined content of wood $(\mathrm{W})$ and shrub (N) remains on a scale of $0=$ nil to $3=$ high content: Hobbs 1986) which were not always laterally continuous and often only found as samples were being extracted from the profile. Between about $1.5 \mathrm{~m}$ and 1.80-1.85 $\mathrm{m}$ deep, wood/shrub fragments varied between $\mathrm{V}_{1}$ and $\mathrm{V}_{3}$ but this layer of brown peat contained several discrete oxidised grey water-filled cracks/zones along which the peat mass readily falls apart. Such features are common in the highly humified lower layers of Irish and Northern Irish blanket peats (e.g. Dykes and Kirk 2006; Dykes 2008d; e.g. Fig. 6). The bottom 50-100 mm of the peat was generally grey (rather than 
brown), amorphous, very stiff and sticky, clay-like but with occasional significant (e.g. 10-20 mm diameter) woody roots and stems $\left(\mathrm{V}_{2}-\right.$ comprising $\left.\mathrm{W}_{2} \mathrm{~N}_{1}\right)$.

Table 2. Peat profile description.

\begin{tabular}{|c|c|c|}
\hline \multicolumn{2}{|l|}{ Depth (mm) } & Description $^{1}$ \\
\hline \multicolumn{2}{|l|}{$0-70$} & woody (heather) living roots and moss \\
\hline \multicolumn{2}{|l|}{$70-670$} & soft: $\mathrm{H}_{6}$ (top) to $\mathrm{H}_{8}$ (bottom), $\mathrm{F}_{3} \mathrm{R}_{1} \mathrm{~W}_{0} \mathrm{~N}_{0}$ \\
\hline \multicolumn{2}{|l|}{$670-920$} & stiff: $\mathrm{H}_{8} \mathrm{~F}_{2} \mathrm{R}_{1} \mathrm{~W}_{0} \mathrm{~N}_{0} \quad$ (very dark brown) \\
\hline \multicolumn{2}{|l|}{$920-1570$} & stiff: $\mathrm{H}_{9} \mathrm{~F}_{2} \mathrm{R}_{0} \mathrm{~W}_{0} \mathrm{~N}_{0} \quad$ (dark brown) \\
\hline \multirow{2}{*}{$1570-1970$} & upper & stiff: $\mathrm{H}_{9} \mathrm{~F}_{1} \mathrm{R}_{0} \mathrm{~W}_{0} \mathrm{~N}_{0} \quad$ (less dark than above) \\
\hline & lower & very stiff: $\mathrm{H}_{9} \mathrm{~F}_{0} \mathrm{R}_{0} \mathrm{~W}_{0} \mathrm{~N}_{0}$ - like clay (less dark than above) \\
\hline
\end{tabular}

Note:

${ }^{1}$ Von Past classification scheme: $\mathrm{H}=$ humification $(1=$ no decomposition to 10 = complete decomposition); $\mathrm{F}=$ fine fibres $<1 \mathrm{~mm}$ diameter or width; $\mathrm{R}=$ coarse fibres $>1$ mm diameter or width; $\mathrm{W}=$ wood content; $\mathrm{N}=$ shrub content $(\mathrm{F}, \mathrm{R}, \mathrm{W}, \mathrm{N}$ : $0=$ nil to $3=$ high content) (Landva and Pheeney 1980; Hobbs 1986; after von Post 1922)

\section{$<$ FIGURE $6>$}

Figure 6. An example of a structural weakness within a peat mass identical to features found at Croaghan (for scale, the pen is $\sim 140 \mathrm{~mm}$ long). The pen is lying on a horizontal step, in front of a vertical face, cut into the lower peat for the purpose of extracting intact block samples. The white arrows identify a pre-existing crack, which formed a continuous irregular discontinuity inclined at approximately $45^{\circ}$ upwards away from the camera into the peat. The peat was weathered grey along the crack; in places semi-liquid peat slurry flowed out when intact peat was lifted clear of the crack. This example was at Slieve Rushen, Co. Cavan; those found at Croaghan could not be photographed because they were simultaneously discovered and destroyed by the sampling work.

\subsection{Physical properties of peat}

The ranges of values of the physical properties of the peat are consistent with those reported from other significant peat landslides in the north and northwest of the island of Ireland (e.g. Boylan and Long 2010, 
2014; Yang and Dykes 2006; Dykes 2008b,c; Dykes and Warburton 2008b; Dykes et al. 2008). There appear to be some clear depth variations comparable with previous studies (Fig. 7). However, a reduction of saturated hydraulic conductivity, $\mathrm{k}_{\mathrm{sat}}$, with depth has not previously been demonstrated due to results from several different profile sites being presented together (Dykes 2008b; Dykes et al. 2008), although Kirk (2001) reported that horizontal $k_{\text {sat }}$ reduced with depth (as is the case here: Fig. 7B) while vertical $k_{\text {sat }}$ increased with depth. Fig. 8 suggests two relationships between physical properties that have also not been identified from previous studies elsewhere. Both are statistically significant $(\mathrm{p}<0.01)$ but lack corroborating replication.

This paper relies on the von Post qualitative assessment of coarse and fine fibre contents on a 4-point scale (von Post 1922; Landva and Pheeney 1980; Hobbs 1986) to provide an outline indication of the nature of the plant remains within the peat. A more rigorous assessment would be to quantify a 'fibre content' as a proportion of the peat mass following ASTM (2008) (e.g. Boylan and Long 2010; Zhang and O’Kelly 2014; Hendy et al. 2014), and findings from the first detailed investigation of botanical controls on the properties of peat (Foteu Madio 2013) are reported in this issue (Foteu Madio and Dykes 2018). The latter work provides a means to suggest whether the botanical composition of the peat at Croaghan is similar to the uplands 150 $\mathrm{km}$ further southwest.

\section{$<$ FIGURE $7>$}

Figure 7. Depth variations of physical properties of peat. (A) Von Post fibre contents and degree of humification. (B) Saturated hydraulic conductivity: open circles = individual values for each depth; black circles = mean value for each depth. (C) Volumetric water content: open circles = field-wet; black circles = saturated. (D) Ash content (1 - loss on ignition), showing individual data values. $($ E) Mass fraction water content: open circles = field-wet; black circles = saturated. (F) Bulk density: crosses = dry; open circles = field wet; black circles = saturated.

\section{$<$ FIGURE $8>$}

Figure 8. (A) Correlation between saturated hydraulic conductivity and saturated bulk density, based on the mean values of each variable for each depth. (B) Correlation between saturated water content and dry bulk density, based on the mean values of each variable for each depth. 


\subsection{Geotechnical properties of peat}

Uncorrected readings obtained from the field shear vane increase with depth from around 10 to around 50 $\mathrm{kPa}$, consistent with observations from other locations. No corrections were applied because the unreliability of field vanes is well established (e.g. Helenelund 1967; Landva 1980; Long 2005; Dykes 2008d; Dykes and Jennings 2011; Boylan and Long 2014) so I simply record the results as being inconsistent with all other measures of peat strength presented below. All three replicate measurements at each depth picked out a weak zone just above the lowest stratigraphic layer (Fig. 5; Table 2) which shows that a vane may be useful for some initial qualitative assessments of peat strength variations. However, it is of little practical use as a means of estimating the available shear strength.

The odeometer test results suggested that both the upper and lower peat layers possess a preconsolidation stress ( $\mathrm{p}_{\mathrm{c}}$ ') which is in the range $10 \mathrm{kPa}$ to $15 \mathrm{kPa}$ indicating the material is lightly overconsolidated. Results from the DSS tests (Fig. 9) show that values of undrained shear strength, $\mathrm{s}_{\mathrm{u}}$, vary between $5 \mathrm{kPa}$ and $6 \mathrm{kPa}$ with an average of about $5.3 \mathrm{kPa}$. Note that $\mathrm{s}_{\mathrm{u}}$ is recorded at a shear strain of $15 \%$. Despite the small range in the resulting $\mathrm{s}_{\mathrm{u}}$ values, there seems to be some trend of decreasing $\mathrm{s}_{\mathrm{u}}$ with increasing water content. This is consistent with the trend suggested by Boylan (2008) for a number of Dutch and Irish peats.

As the DSS samples were initially consolidated to a specified stress it is important to examine the influence of consolidation stress on the resulting strength. In Figure 9 the normalised $\mathrm{s}_{\mathrm{u}} / \sigma_{\mathrm{v}}$ ' values are plotted against consolidation stress. Despite the low range of stresses involved there is a strong more or less linear relationship between these two parameters. The $\mathrm{s}_{\mathrm{u}} / \sigma_{\mathrm{v}}{ }^{\prime}$ values decrease from about 0.8 at the lowest stress to about 0.5 at just over $10 \mathrm{kPa}$. It can be seen that values the $\mathrm{s}_{\mathrm{u}} / \sigma_{\mathrm{v}}$ ' values are approaching, but have not yet reached, the value of 0.4 for normally consolidated peat suggested by Carlsten (2000) for Swedish peat. Boylan (2008) reports on the work of several other authors who obtained similar results to Carlsten. These results are consistent with the oedometer tests in suggesting a preconsolidation stress in the range 10-15 kPa; this range is also given by O’Kelly (2017).

\section{$<$ FIGURE $9>$}

Figure 9. Results from the Direct Simple Shear (DSS) tests. (A) Undrained shear strength, $\mathrm{s}_{\mathrm{u}}$, versus water content on shearing. (B) Normalised undrained shear strength, $\mathrm{s}_{\mathrm{u}} / \sigma_{\mathrm{v}}$ ', versus vertical consolidation stress, $\sigma_{\mathrm{v}}$ '. 
Fig. 10A shows the variability of the tensile strength of the peat at five sampling depths in the profile, highlighting a reduction from around $3 \mathrm{kPa}$ near the surface to around $0.5 \mathrm{kPa}$ at the base. The mean value for each depth reflects the fact that most of the results obtained from each depth were clustered around the lowest strength, suggesting that the primary control on this measure of strength was from fibres within an amorphous matrix. Most of the scatter arose from higher strengths resulting from occasional more resistant plant remains such as woody fragments. The testing procedure (outlined in Foteu Madio and Dykes 2018) is expected to produce 1-3 results from each collected sample, so the collection of at least three samples from each position must be regarded as a minimum requirement to obtain reliable estimates of tensile strength at any given position in a peat mass.

Fig. 10B suggests that there is a relationship between the tensile strength (from 'TS' samples in Fig. 5) and the saturated hydraulic conductivity (from 'WC' samples in Fig. 5), these results having been obtained from different sets of samples because the tests required different sample geometries. Although statistically significant $(\mathrm{p}<0.01)$, this relationship has not been found before and lacks corroborating replication. It can be explained, however, in terms of higher tensile strength being associated with a higher frequency of reinforcing fibres and, hence, greater likelihood of discrete micropores around and between the fibres, in contrast to the more uniformly amorphous colloidal material at greater depth.

\section{$<$ FIGURE $10>$}

Figure 10. (A) Variations in tensile strength with depth: open circles = individual values for each depth; black circles = mean value for each depth (main cluster of results only). (B) Correlation between tensile strength and saturated hydraulic conductivity $\left(\mathrm{K}_{\mathrm{sat}}\right)$, based on the mean values of each variable for each depth (except TS value for $1.12 \mathrm{~m}$ depth plotted against $\mathrm{K}_{\text {sat }}$ values for $1.02 \mathrm{~m}$ and $1.245 \mathrm{~m}$ depth).

\subsection{Stability analysis}

A simple back-analysis (Chandler 1977) of the peat slide was done using the infinite slope model (Haefeli 1948), assuming the failure to have been planar at a slope of $6.5^{\circ}$ with a mean peat depth of $2.5 \mathrm{~m}$, unit weight $=10 \mathrm{kN} \mathrm{m}^{-3}$ and water table assumed to be at the surface with flow parallel to the surface. If the 
friction angle, $\phi=0$ representing undrained failure, the cohesion required for stability ( $\mathrm{F}=1.0)$ is $2.9 \mathrm{kPa}$. If a drained failure is represented with $\phi^{\prime}=30^{\circ}$ (e.g. Kirk 2001; Long and Jennings 2006), the cohesion required for stability ( $\mathrm{F}=1.0)$ is $2.6 \mathrm{kPa}$.

\section{Discussion}

The Croaghan peat slide of August 2014 appears to have occurred because the lowest layer of the peat is very weak, with Direct Simple Shear and tensile strength methods both indicating the peat (shear) strength to be consistent with previous studies of Irish peat failures, resulting from the degree of decomposition of a botanical assemblage very similar to the upland peats of Counties Sligo/Leitrim/Cavan. This peat-covered slope was susceptible to rainfall-triggered failure because of the peat mass characteristics, including the weak basal layer, and hydrological slope context. These findings are examined in more detail below.

\subsection{Peat strength}

The shear strength of the basal peat at the Croaghan peat slide is less than $6 \mathrm{kPa}$ and most likely less than 5 $\mathrm{kPa}$. The mean DSS shear strength of $5.3 \mathrm{kPa}$ was obtained from samples consolidated to an estimated preconsolidation stress of perhaps slightly more than $10 \mathrm{kPa}$. The tensile strength, which reduced with depth from 3 to $0.5 \mathrm{kPa}$, was obtained from unconfined samples but can be regarded as a reasonable indication of the general peat strength (Helenelund 1967; O’Kelly 2017). A routine back-analysis of the landslide suggests that a cohesion of $3 \mathrm{kPa}$ would be sufficient to maintain stability with respect to hydrostatic plus seepage water pressures.

The tensile strength of peat may provide a more reliable indication of overall peat strength than other measures (O'Kelly 2017), and it is reasonable to suggest that the lowest measured tensile strength from any set of measurements (e.g. for each peat depth in this case) would control the overall stability condition of the peat. Even if the limitations of the methodology mean that the peat strength is underestimated slightly (Dykes 2008d), the mean value from nine replicated tests on basal peat is less than $2 \mathrm{kPa}$ (Fig. 10A), consistent with results from other Irish blanket bogs. The observed large stones and tree remains on the exposed failure surface must have provided some additional resistance to basal shearing, and if failure 
resulted from some localised artesian water pressures (e.g. Dykes and Warburton 2008a) then the mobilised shear strength at failure may have been slightly higher still, i.e. closer to the DSS value. Notwithstanding the above details, such a small amount of cohesion would normally be ignored in engineering analyses of rock or (mineral) soil slope stability. The tensile strengths appear to be over-conservative compared with the DSS results but the latter approach is itself considered to give conservative estimates of peat strength (O’Kelly 2015). However, both measures are indicating the available (shear) strength of the peat to be of the same order of (extremely low) magnitude, i.e. probably less than $5 \mathrm{kPa}$ overall.

Taken with similar results from Counties Kerry (Dykes and Jennings 2011), Clare, Mayo, Fermanagh (Dykes 2008c), Sligo, Leitrim and Cavan (Foteu Madio and Dykes 2018), this result from Co. Antrim indicates that most (if not all) of Ireland's deeper blanket peat is extremely weak at the base. Consequently, it appears unwise for a shear strength of higher than $5 \mathrm{kPa}$ to be assumed for any engineering assessment of works affecting in-situ blanket peat more than $2 \mathrm{~m}$ deep, anywhere in Ireland.

Overconsolidation of Irish blanket peat has been found previously (e.g. Boylan and Long 2014; Zhang and O’Kelly 2014) and this is now assumed to be the normal state of the peat (O’Kelly 2017). The normally expected range of water table fluctuation would produce an effective normal stress on the basal peat of up to around $5 \mathrm{kPa}$, so it appears that the post-depositional history of the peat has experienced some environmental conditions significantly outside the range of present climatic conditions. Hobbs (1986) discussed several possible mechanisms that may account for such overconsolidation, mostly relating to fen peat and raised bog contexts. Some, such as wetting/drying and differential decomposition effects, may be relevant to upland blanket bogs. Perhaps more likely for the latter contexts may be the effects of occasional loading such as from snow during one or more prolonged periods of extreme cold weather (e.g. the 'Little Ice Age' from the 14th to mid-19th centuries). Accumulated snow quickly attains a unit weight of the order of $2.5 \mathrm{kN} \mathrm{m}^{-3}$ (Wold 1987) so that the measured overconsolidation could have resulted from 4-6 m depth of snow.

\subsection{Botanical composition}

The measured properties of the peat at the Croaghan peat slide are consistent with corresponding values obtained from other blanket bogs and bog peats in raised bogs throughout Ireland (e.g. Boylan and Long 
2010, 2014; Dykes 2008b,d; Dykes and Warburton 2008b; Dykes et al. 2008; Dykes and Jennings 2011). The depth relationships between some parameters that have not previously been found so clearly within a single peat profile (or indeed at a single site) enhances confidence in the consistency of results from the different approaches to the determination of the strength of the peat. In particular, the values of the measured properties are entirely in line with those obtained from three large bogflows in northwestern Ireland that were used for the first systematic investigation of botanical controls on peat properties (Table 4 in Foteu Madio and Dykes 2018).

Foteu Madio and Dykes (2018) found that the blanket bogs at three entirely separate uplands comprised essentially the same assemblages of plant species, as determined by analyses of macrofossil contents. The peat was dominated by monocotyledon plants, particularly Eriophorum vaginatum and other sedges, but with other plants common to the present living vegetation cover (heathers - Ericacae, including Calluna vulgaris, and mosses including some Sphagnum) also represented. The results from the first phase of the Croaghan study suggest that the peat properties here most likely result from the same botanical composition as established by Foteu Madio and Dykes (2018). The limitations of these Croaghan results for more detailed analysis arise from the lack of replication of the peat profile investigation. Thus far no statistical measures of the small-scale spatial variability of peat properties have been obtained due to the difficulty of cutting even one a fresh profile in the marginal scar of a peat landslide, although peat stratigraphy has been shown to sometimes vary considerably across a site based on hand auger samples (Foteu Madio 2013). Therefore the significance of the relationships shown in Figs. 8 and 10B, for example, cannot yet be assessed.

Foteu Madio and Dykes (2018) also showed a basal layer much weaker than overlying peat, around $150 \mathrm{~mm}$ thick, characterised by distinctly fewer fibres (particularly coarse fibres). Fig. 7 suggests a similar scenario at Croaghan. The fibre content of the peat has been identified previously, at other locations, as a determining factor for the stability of Irish blanket peat (e.g. Boylan and Long 2010). The fibre content represents a direct botanical control on the properties and behaviour of the peat mass since the nature (sizes, forms, tensile strengths, shear strength against amorphous matrix, etc.) and persistence (rate of decomposition compared with adjacent plant matter and associated frequency or density) of fibres depends on the species of plants that contributed to the accumulating peat. Some studies have suggested that fibre contents have no influence on 
geotechnical properties (Price et al. 2005; Hendy et al. 2014). However, Irish upland blanket bog can rarely be considered to be 'fibrous' in the manner of 'fibrous peats'. Although only a subjective estimate based on the von Post 'squeeze test', Fig. 7A strongly suggests a continuous decrease in the density of fibres with depth in the peat that corresponds with the increasing degree of humification as would be expected.

\subsection{Peat mass characteristics}

There appear to be two fundamental controls on the strength and stability of Irish upland blanket peat, both of which are demonstrated here: (i) botanical composition, and (ii) peat mass structure. The botanical composition and the occurrence of a basal layer much weaker than the overlying peat are discussed above. The second fundamental control is the presence of natural, or indeed anthropogenic, structural weaknesses within and potentially throughout the peat mass. From about 1960 to 2008, slightly more than $50 \%$ of upland blanket peat failures in Ireland were associated with artificial disturbance to the structural integrity of the peat mass (Dykes 2008a). The 'mechanical' dangers of such disturbance have been reported many times and are well known (O’Kelly 2017) and there may be some associated adverse microbiological effects (O’Kelly and Pichan 2014). However, within undisturbed peat there are several types of natural discontinuities that provide zones of locally reduced overall mean strength and potential pathways for rainwater to penetrate the mass and generate adverse hydraulic effects: (i) pipes of various shapes, sizes and degrees of connectedness, (ii) subvertical cracks originally formed due to surface drying and shrinkage and which may persist as discontinuities within lower peat layers when sufficiently buried beneath subsequent peat accumulation, (iii) enclosed small bodies of liquid oxidised peat (e.g. up to 1 litre) that probably originated as small pools of water at the surface that became covered over by dead plant matter and then incorporated into the peat without being infilled with plant debris, and (iv) randomly oriented cracks containing similar oxidised liquid sludge (Fig. 6). Whilst peat pipes have been documented and investigated in detail in association with peat landslides (Dykes and Warburton 2007a) and peat hydrology research (e.g. Holden and Burt 2002, 2003), to the best of my knowledge nothing is yet known about the (3-dimensional) spatial frequency of occurrence of the other features. Together they potentially create a requirement to consider peat mass strength in the sense of 'rock mass strength' rather than focusing solely on the strength of the peat material. All of the above features were present at Croaghan. 


\subsection{Explanation for the landslide}

Details of the peat properties and peat mass characteristics have been examined. It is assumed that the properties were broadly similar across the slope that failed, and that examples of the structural weaknesses were randomly distributed across the site. Fig. 2 shows that the peat was generally very slightly deeper down the western side of the failed area, but that around $90 \mathrm{~m}$ downslope from the head of the landslide the peat became significantly thinner. Under conditions of storm runoff possibly causing pressurised macropore flow, such a geometric feature would provide a natural predisposition to failure (e.g. Dykes and Warburton 2008b). Given all of the site details and material properties reported in this paper, it is now possible to suggest how and why this slope failed.

The Croaghan peat slide occurred because of intense rainfall, following a rather dry period of weather (Fig. 4, Table 1), entering the blanket peat by means of pipes and surface desiccation cracks. This rainwater caused a rapid build up of excess water pressures throughout the macropore network, including pre-existing structural cracks and voids normally filled with oxidised and highly fluid peat slurry. The drainage channel above the head of the landslide (Figs. 1C, 2) feeds a pipe network that, if filled with water, would generate artesian pressures within the pipes and other structural voids that connect with them, evidence for which effect has been seen (e.g. Dykes and Warburton 2007a, 2008a) and discussed (Holden and Burt 2003; Warburton et al. 2004) elsewhere. Dykes and Warburton (2008a) discussed the effect of such artesian pressures for stability, highlighting the fact that 'any upward hydraulic stress at the peat-mineral interface is proportionally greater in thinner peat' (p.221) and they also showed how similar contexts could promote instability at the Dooncarton Mountain peat slides in western Ireland (Dykes and Warburton 2008b). Failure occurred because the combined effects of extreme hydrological and hydraulic conditions arising from the above mechanisms were sufficient to overcome the extremely low overall shear strength of the weak basal layer of the peat.

\section{Conclusions}

The Croaghan peat slide of August 2014 was triggered by heavy rainfall but ultimately occurred because of a basal layer of very weak peat arising from the decomposition profile of the constituent plant remains. Two 
methods for estimating the shear strength of peat, Direct Simple Shear and tensile strength testing, were directly compared for the first time using adjacent samples from the same peat profile. Both methods produced (shear) strengths less than $6 \mathrm{kPa}$, i.e. in geotechnical terms, effectively the same as the cohesion of $3 \mathrm{kPa}$ required for stability determined from back-analysis of the landslide. Both methods are therefore shown to be broadly reliable, although the DSS strength may be slightly high and the tensile strength may be somewhat conservative. In any case, the geographical spread of similar strength values from lower layers in blanket peat of around $2 \mathrm{~m}$ or more in depth across Ireland leads to a general recommendation that any engineering assessment should assume that the available shear strength at the base of the peat is less than 5 $\mathrm{kPa}$, i.e. significantly lower than a field vane would indicate.

The properties of the peat at the Croaghan peat slide are effectively the same as at three separate locations $150 \mathrm{~km}$ further southwest. At those locations, the botanical composition of the peat was found to comprise mostly the remains of monocotyledon plants, i.e. sedges such as (primarily) E. vaginatum. Therefore it is inferred that the botanical composition of the peat at Croaghan is the same. This is also consistent with a near absence of fibres towards the base of the peat due to very high decomposition, giving rise to the weak basal layer. High subsurface water pressures resulting from the extreme rainfall, combined with the low strength of this layer, allowed failure to occur across a planar surface just above the level of large stones or woody fragments at the base of the peat.

\section{Acknowledgements}

I am grateful to Dr Mike Long who assisted this research by conducting the oedometer and DSS tests at University College Dublin and commenting on the manuscript. Permission to undertake research on the landslide at Croaghan was granted by the Northern Ireland Environment Agency. Thanks also to Dessy Henry of Scottish Woodlands (manager of the land) for supporting our research and obtaining the NIEA permission, and to Dermot McAleese and Derek Anderson for additional information about the landslide. We acknowledge the UK Met Office Hadley Centre for making HadUKP data available under the Open Government License (www.metoffice.gov.uk/hadobs). 


\section{References}

Alexander LV and Jones PD (2001) Updated precipitation series for the U.K. and discussion of recent extremes. Atmospheric Science Letters 1(2), 142-150. https://doi.org/10.1006/asle.2001.0025.

Andrejko MJ, Fiene F and Cohen AD (1983) Comparison of ashing techniques for determination of the inorganic content of peats. In Jarrett PM (ed) Testing of peats and organic soils. ASTM Special Technical Publication 820, Philadelphia, pp 5-20.

Andresen A, Berre T, Kleven A and Lunne T (1979) Procedures used to obtain soil parameters for foundation engineering in the North Sea. Marine Geotechnology 3(3), 201-266. https://doi.org/10.1080/10641197909379804.

ASTM (2008) D1997-91: Standard test method for laboratory determination of the fiber content of peat samples by dry mass. ASTM International, West Conshohocken, PA, USA.

Bell FG (2000) Engineering Properties of Soil and Rocks (4th Edition). Blackwell, Oxford.

Bell FG and Maud RR (2000) Landslides associated with the colluvial soils overlying the Natal Group in the greater Durban region of Natal, South Africa. Environmental Geology 39(9), 1029-1038. https://doi.org/10.1007/s002549900077.

Best B (2014) Torrential rain leads to landslides in County Antrim. BBC News Northern Ireland, British Broadcasting Corporation. Available at: www.bbc.co.uk/news/uk-northern-ireland-28637481 [accessed 30 June 2017].

Bjerrum L and Landva AO (1966) Direct simple-shear tests on a Norwegian quick clay. Géotechnique 16(1), 1-20. https://doi.org/10.1680/geot.1966.16.1.1.

Boylan N (2008) The shear strength of peat. Unpublished PhD thesis, University College Dublin, Dublin, Ireland.

Boylan N and Long M (2010) An investigation of two peat slope failures in the Wicklow mountains Biology and Environment. Proceedings of the Royal Irish Academy 110B (3), 173-184. https://doi.org/10.3318/BIOE.2010.110.3.173.

Boylan N and Long M (2014) Evaluation of peat strength for stability assessments. Geotechnical Engineering 167(5), 421-430. https://doi.org/10.1680/geng.12.00043.

Boylan N, Long M, Mathijssen FAJM (2011) In situ strength characterisation of peat and organic soil using full-flow penetrometers. Canadian Geotechnical Journal 48(7), 1085-1099. https://doi.org/10.1139/t11-023.

BS1377 (1990) BS1377:1990 Methods of test for soils in civil engineering. British Standards Institute, London.

Carlsten P (1993) Peat-geotechnical properties and up-to-date methods of design and construction. State-of-the-artreport, 2nd edn. Report No. 215, Swedish Geotechnical Institute, Linköping.

Carlsten P (2000) Geotechnical properties of some Swedish peats. Proceedings of the 13th NGM, Nordiska Geoteknikermötet, Helsinki, Finland, pp.51-60.

Chandler RJ (1977) Back analysis techniques for slope stabilization works: a case record. Géotechnique 27(4), 479-495. https://doi.org/10.1680/geot.1977.27.4.479. 
DAERA (2015) Slieveanorra and Croaghan ASSI. Department of Agriculture, Environment and Rural Affairs, Belfast. Available at: https://www.daera-ni.gov.uk/publications/slieveanorra-croaghan-assi [accessed 1 July 2017].

Dykes, A P (2008a) Natural and anthropogenic causes of peat instability and landslides. In After Wise Use - The Future of Peatlands (Farrell C and Feehan, J (eds)). Proceedings of the 13th International Peat Congress (Vol. 1). International Peat Society, Jyväskylä, pp.39-42.

Dykes AP (2008b) Properties of peat relating to instability of blanket bogs. In Landslides and Engineered Slopes (Chen Z-Y, Zhang J, Li Z, Wu A and Ho K (eds)). Proceedings of the 10th International Symposium on Landslides and Engineered Slopes (Vol. 1). Taylor and Francis, London, 339-345.

Dykes AP (2008c) Tensile strength of peat and its role in Irish blanket bog failures. Landslides 5(4), 417-429. https://doi.org/10.1007/s10346-008-0136-1.

Dykes AP (2008d) Geomorphological maps of Irish peat landslides created using hand-held GPS. Journal of Maps 4(1), 258-276. https://doi.org/10.4113/jom.2008.1029.

Dykes AP (2012) The role of forestry in the failure of peat-covered slopes in Ireland. In Landslides and Engineered Slopes: Protecting Society through Improved Understanding (Eberhardt E, Froese C, Turner AK and Leroueil S (eds)). Proceedings of the 11th International and 2nd North American Symposium on Landslides and Engineered Slopes (Vol. 2). CRC Press, London, 1649-1655.

Dykes AP and Jennings P (2011) Peat slope failures and other mass movements in western Ireland, August 2008. Quarterly Journal of Engineering Geology and Hydrogeology 44(1), 5-16. https://doi.org/10.1144/1470-9236/09$\underline{020}$.

Dykes AP and Kirk KJ (2001) Initiation of a multiple peat slide on Cuilcagh Mountain, Northern Ireland. Earth Surface Processes and Landforms 26(4), 395-408. https://doi.org/10.1002/esp.188.

Dykes AP and Kirk KJ (2006) Slope instability and mass movements in peat deposits. In Martini IP, Martínez Cortizas A, Chesworth W (eds) Peatlands: Evolution and Records of Environmental and Climate Changes. Elsevier, Amsterdam, pp. 377-406.

Dykes AP and Warburton J (2007a) Geomorphological and subsurface drainage controls on failures of peat-covered hillslopes triggered by extreme rainfall. Earth Surface Processes and Landforms 32(12), 1841-1862. https://doi.org/10.1002/esp.1499.

Dykes AP and Warburton J (2007b) Mass movements in peat: a formal classification scheme. Geomorphology 86(1-2), 73-93. https://doi.org/10.1016/j.geomorph.2006.08.009.

Dykes AP and Warburton J (2008a) Characteristics of the Shetland Islands (UK) peat slides of 19 September 2003. Landslides 5(2), 213-226. https://doi.org/10.1007/s10346-008-0114-7.

Dykes AP and Warburton J (2008b) Failure of peat-covered hillslopes at Pollatomish, Co. Mayo, Ireland: analysis of topographic and geotechnical factors. Catena 72(1), 129-145. https://doi.org/10.1016/j.catena.2007.04.008.

Dykes AP, Gunn J and Convery (Née Kirk) KJ (2008) Landslides in blanket peat on Cuilcagh Mountain, northwest Ireland. Geomorphology 102(3-4), 325-340. https://doi.org/10.1016/j.geomorph.2008.04.003. 
Foteu Madio ES (2013) Physical and geotechnical influences on peat instability. Unpublished PhD thesis, Kingston University, Kingston upon Thames, UK.

Foteu Madio ES and Dykes AP (2018) Botanical and geotechnical characteristics of blanket peat at three Irish bogflows. Environmental Geotechnics, published ahead of print at http://doi.org/10.1680/jenge.17.00089.

Foteu Madio ES, Dykes AP, Waller MP, Hughes P and Grant MJ (2012) Botanical and geotechnical influences on peat instability. In Landslides and Engineered Slopes: Protecting Society through Improved Understanding (Eberhardt E, Froese C, Turner AK and Leroueil S (eds)). Proceedings of the 11th International and 2nd North American Symposium on Landslides and Engineered Slopes (Vol. 2). CRC Press, London, 421-427.

Haefeli R (1948) The stability of slopes acted upon by parallel seepage. In: International Conference on Soil Mechanics and Foundation Engineering, 57-62.

Hammond RF (1979) The Peatlands of Ireland. Survey Bulletin No. 35. An Foras Talúntais, Dublin.

Helenelund KV (1967) Vane tests and tension tests on fibrous peat. Proceedings of the Geotechnical Conference, Oslo, 1, 199-203.

Hendy MT, Barbour SL and Martin CD (2014) Evaluating the effect of fiber reinforcement on the anisotropic undrained stiffness and strength of peat. Journal of Geotechnical and Geoenvironmental Engineering, published on-line at doi:10.1061/(ASCE)GT.1943-5606.0001154.

Hobbs NB (1986) Mire morphology and the properties and behaviour of some British and foreign peats. Quarterly Journal of Engineering Geology 19(1), 7-80. https://doi.org/10.1144/GSL.QJEG.1986.019.01.02.

Holden J and Burt TP (2002) Laboratory experiments on drought and runoff in blanket peat. European Journal of Soil Science 53(4), 675-689. https://doi.org/10.1046/j.1365-2389.2002.00486.x.

Holden J and Burt TP (2003) Hydrological studies on blanket peat: the significance of the acrotelm-catotelm model. Journal of Ecology 91(1), 103-113. https://doi.org/10.1046/j.1365-2745.2003.00748.x.

Jarrett PM (1983) Summary. In Jarrett PM (ed) Testing of Peats and Organic Soils. ASTM Special Technical Publication, vol. 820. Philadelphia, pp. 233-237.

Kirk KJ (2001) Instability of blanket bog slopes on Cuilcagh Mountain, N.W. Ireland. Unpublished PhD thesis. University of Huddersfield, UK.

Landva AO (1980) Vane testing in peat. Canadian Geotechnical Journal, 17(1), 1-19. https://doi.org/10.1139/t80-001.

Landva AO and Pheeney PE (1980) Peat fabric and structure. Canadian Geotechnical Journal 17(3), 416-435. https://doi.org/10.1139/t80-048 .

Li W, O’Kelly BC, Fang K and Yang M (2018) Water content determinations for peaty soil using the oven-drying method. Environmental Geotechnics, published ahead of print at http://doi.org/10.1680/jenge.18.00056.

Lindsay R and Bragg O (2005) Wind farms and blanket peat: a report on the Derrybrien bog slide. Derrybrien Development Cooperative Ltd., Gort, Ireland.

Long M (2005) Review of peat strength, peat characterisation and constitutive modelling of peat with reference to landslides. Studia Geotechnica et Mechanica 27(3-4), 67-90. No DOI. 
Long M (2016) Croaghan Landslide, Co. Antrim. Report on Direct Simple Shear, Oedometer and Index Tests on Peat. Report 2016-G02, School of Civil Engineering, University College Dublin.

Long M and Jennings P (2006) Analysis of the peat slide at Pollatomish, County Mayo, Ireland. Landslides 3(1), $51-61$. https://doi.org/10.1007/s10346-005-0006-z.

Long M, Jennings P and Carroll R (2011) Irish peat slides 2006-2010. Landslides 8(3), 391-401. https://doi.org/10.1007/s10346-011-0254-z.

Lumb P (1975) Slope failure in Hong Kong. Quarterly Journal of Engineering Geology 8(1), 31-65. https://doi.org/10.1144/GSL.QJEG.1975.008.01.02.

Met Office (2017a) Climate Summaries - links to text and data. The Met Office, Exeter. Available at: http://www.metoffice.gov.uk/climate/uk/summaries [accessed 2 August 2017].

Met Office (2017b) Northern Ireland Rainfall (mm) - data table. The Met Office, Exeter. Available at: http://www.metoffice.gov.uk/pub/data/weather/uk/climate/datasets/Rainfall/date/Northern_Ireland.txt [accessed 2 August 2017].

Moore R, Carey J, Mills A, Martin S, Irinder S, Kerry L, Leask G and Simmons A (2006) Recent landslide impacts on the UK Scottish road network: investigation into the mechanisms, causes and management of landslide risk. In: Ashaari M (ed) Proceedings of the International Conference on Slopes, Kuala Lumpur, Malaysia, 2006. Public Works Department, Kuala Lumpur, 223-237.

NERC (2017) The BGS Lexicon of Named Rock Units - Result Details: Southern Highland Group. British Geological Survey, Natural Environment Research Council, Keyworth. Available at: http://www.bgs.ac.uk/lexicon/lexicon.cfm?pub=SOHI [accessed 1 July 2017].

O’Kelly BC (2015) Effective stress strength testing of peat. Environmental Geotechnics 2(1), 34-44. http://dx.doi.org/10.1680/envgeo.13.00112.

O’Kelly BC (2016) Briefing: Atterberg limits and peat. Environmental Geotechnics 3(6), 359-363. http://dx.doi.org/10.1680/envgeo.15.00003.

O’Kelly BC (2017) Measurement, interpretation and recommended use of laboratory strength properties of fibrous peat. Geotechnical Research 4(3), 136-171. http://dx.doi.org/10.1680/jgere.17.00006.

O’Kelly BC and Pichan SP (2014) Effect of decomposition on physical properties of fibrous peat. Environmental Geotechnics 1(1), 22-32. http://dx.doi.org/10.1680/envgeo.13.00012.

Pasuto A and Silvano S (1998) Rainfall as a triggering factor of shallow mass movements. A case study in the Dolomites, Italy. Environmental Geology 35(2-3), 184-189. https://doi.org/10.1007/s002540050304.

Price JS, Cagampan J and Kellner E (2005) Assessment of peat compressibility: is there an easy way? Hydrological Processes 19(17), 3469-3475. https://doi.org/10.1002/hyp.6068.

Skempton AW and Petley DJ (1970) Ignition loss and other properties of peats and clays from Avonmouth, King's Lynn and Cranberry Moss. Géotechnique 20(4), 343-356. https://doi.org/10.1680/geot.1970.20.4.343. 
von Post L (1922) Sveriges geologiska undersoknings torvinventering och nagre av dess hittills vunna resultat, sr. mosskulturfor. Tidskrift 1, 1-27 (in Swedish). No DOI.

Warburton J, Holden J, Mills AJ (2004) Hydrological controls of surficial mass movements in peat. Earth Science Reviews 67(1-2), 139-156. https://doi.org/10.1016/j.earscirev.2004.03.003.

Winter MG, Barker KJ, Reid JM, Boylan N, Jennings P and Long M (2009) Discussion of 'Peat slope failure in Ireland' by N. Boylan, P. Jennings \& M. Long. Quarterly Journal of Engineering Geology and Hydrogeology, 41, 93-108.

Quarterly Journal of Engineering Geology and Hydrogeology 42(1), 129-132. https://doi.org/10.1144/1470$\underline{9236 / 08-065}$.

Wold K (1987) Specific weight of snow. In Avalanche Formation, Movement and Effects (Salm B and Gubler H (eds)). Proceedings of the Davos Symposium, September 1986, IAHS Publ. No. 162, pp.79-84.

Yang J and Dykes AP (2006) The liquid limit of peat and its application to the understanding of Irish blanket bog failures. Landslides 3(3), 205-216. https://doi.org/10.1007/s10346-006-0038-z.

Zhang L and O’Kelly BC 2014 The principle of effective stress and triaxial compression testing of peat. Geotechnical Engineering 167(1), 40-50. https://doi.org/10.1680/geng.12.00038. 


\section{Figures}

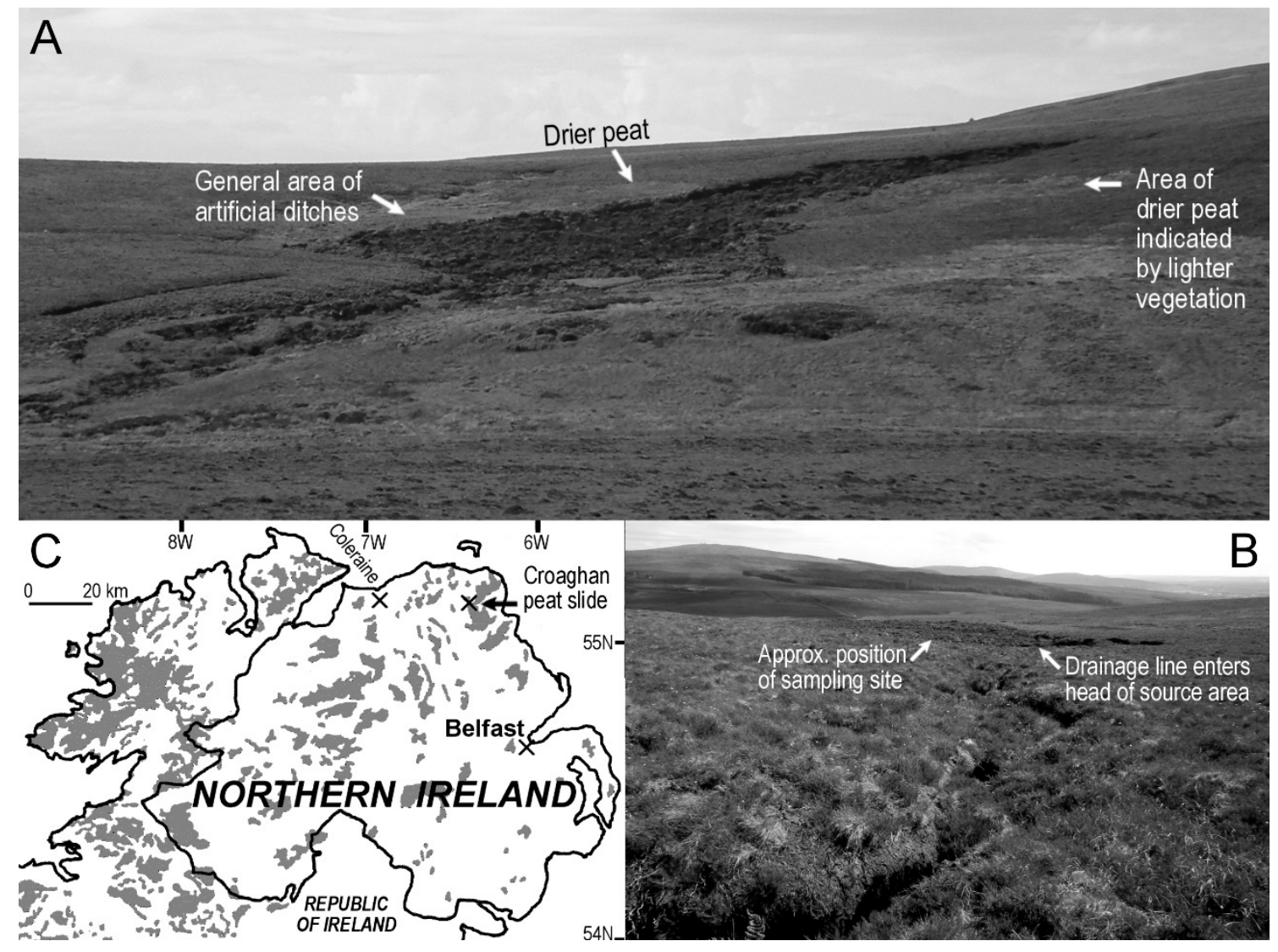

Figure 1. (A) View of the landslide (dark area upper centre) from the southeast indicating slope and drainage features mentioned in the text. A natural drainage line can be seen to the left (west) of the lower source area. (B) View towards the head of the landslide from further upslope, showing the natural drainage line that conveyed runoff towards the failed area of slope. The surface channel ends around $10 \mathrm{~m}$ upslope from the source area and is assumed to drain into one or more subsurface peat pipes. (C) Location of the peat slide in Northern Ireland. Grey shading indicates peatlands (after Hammond 1979). 


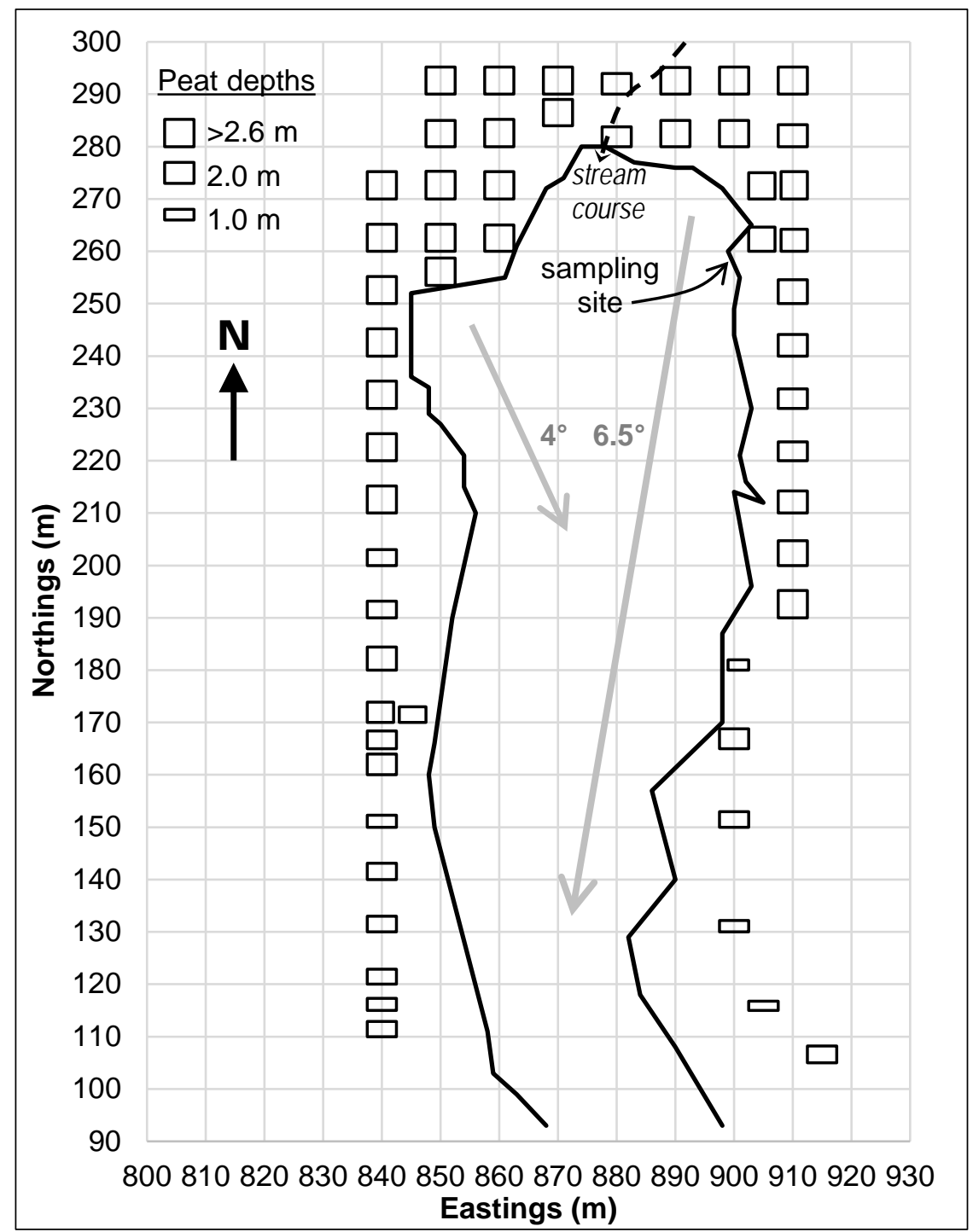

Figure 2. Outline of the peat slide source area showing (i) failure surface gradient, (ii) location of the sampling site, (iii) approximate line of the stream course shown in Fig. 1B, and (iv) depths of undisturbed peat (metres) as measured at the location of the bottom-centre of each scaled rectangle. Coordinates refer to the Irish Grid: Eastings increase from D311800 m, Northings increase from D430090 m. 


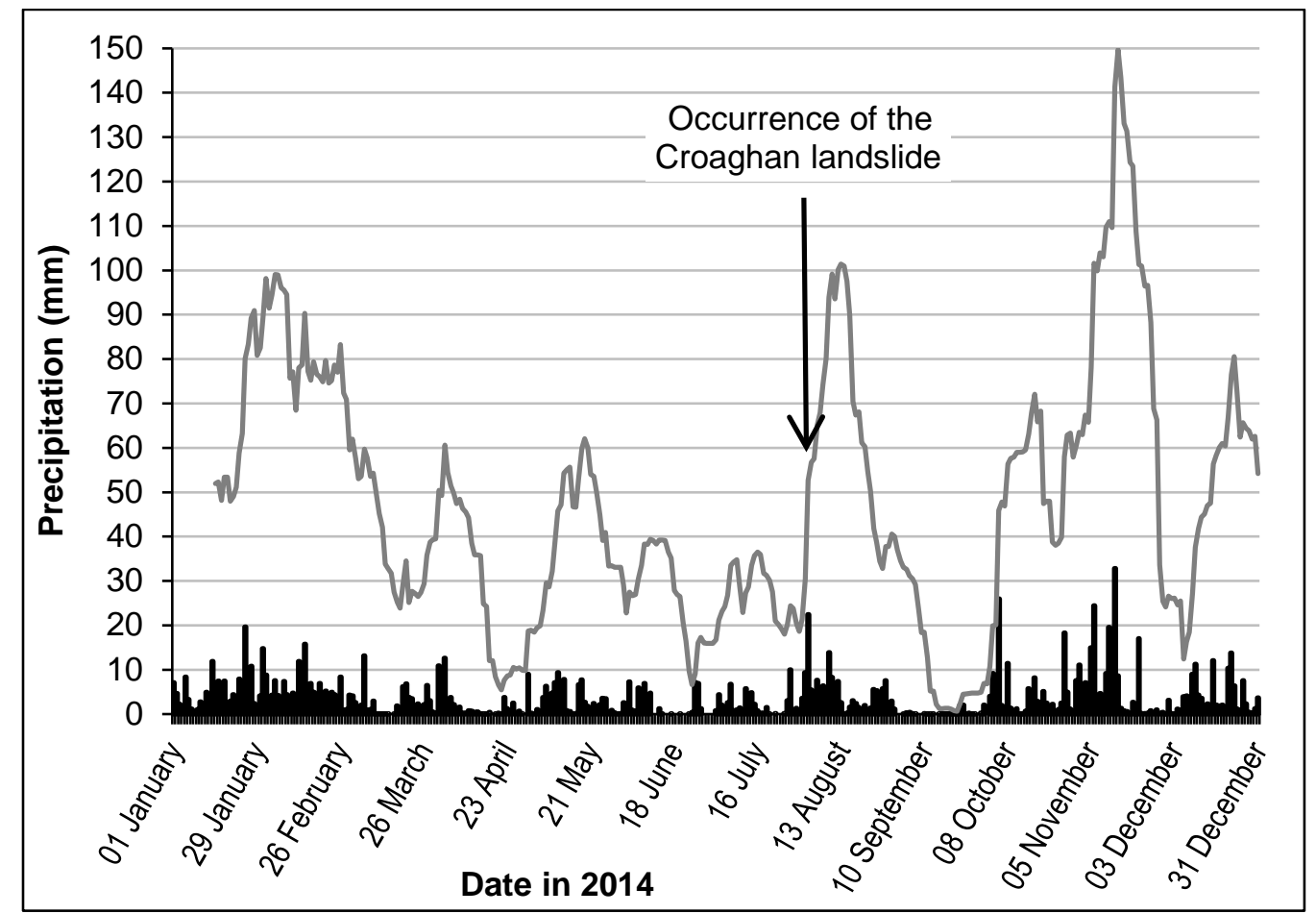

Figure 3. Regional daily precipitation for Northern Ireland for 2014 (black bars) and the corresponding 15-day antecedent precipitation (grey line). Source: Met Office (2017a, after Alexander and Jones 2001). The occurrence of the landslide is indicated by the arrow.

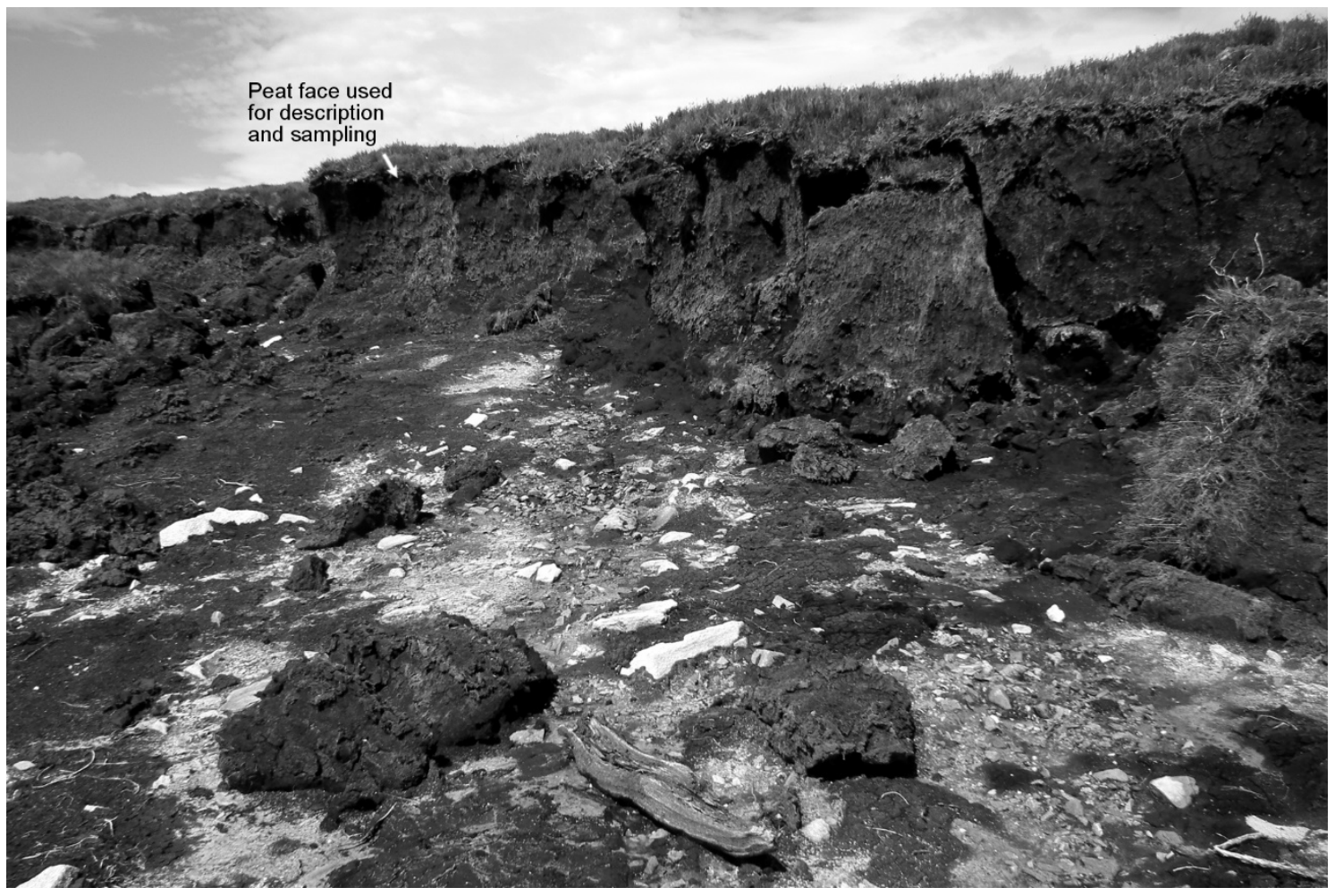

Figure 4. The upper eastern margin of the source area in August 2015 immediately prior to sampling, showing the sampling site and details of the failure surface. Some residual peat has been eroded away, but much of the failure surface was just high enough above the peat-mineral interface to override the large stones (white appearance in this photograph) and remains of ancient trees. The visible piece of wood (bottom centre) is just over $1 \mathrm{~m}$ long and $200 \mathrm{~mm}$ in diameter. 


\begin{tabular}{|c|c|c|c|c|}
\hline & & stratigra & nplin & \\
\hline & Peat layer & WC & TS & DSS \\
\hline 0.1 & & ×ా & & \\
\hline 0.2 & & & & \\
\hline 0.3 & & 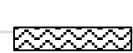 & & \\
\hline 0.4 & & & & \\
\hline 0.5 & & $\infty \approx$ & $38 \%$ & \\
\hline$\widehat{\boldsymbol{\varepsilon}}^{0.6}$ & & & & \\
\hline $\begin{array}{ll}= & 0.7 \\
\Xi & 0.8\end{array}$ & & Fr: & & \\
\hline$\stackrel{\varpi}{\leftrightarrows} 0.9$ & & & & \\
\hline $\begin{array}{ll}3 & 1\end{array}$ & & 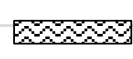 & & \\
\hline 은 1.1 & & & & \\
\hline $\begin{array}{ll}0 & 1.2 \\
= & 13\end{array}$ & & $\approx$ & & \\
\hline 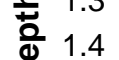 & & & & \\
\hline 1.5 & & $\approx$ & 2, & \\
\hline 1.6 & & & & \\
\hline 1.7 & & 2220 & & \\
\hline 1.8 & & & & \\
\hline 1.9 & & $\approx$ & & \\
\hline 2 & & & & \\
\hline
\end{tabular}

Figure 5. Representation of the peat profile stratigraphy and sampling strategy at the peat face identified in Fig. 4. Brief descriptions of the peat layers are provided in Table 2 . WC $=50 \mathrm{~mm}$ dia. $\times 50 \mathrm{~mm}$ long cores for physical properties (2 from each depth), TS = blocks for tensile strength (3 from each depth), DSS = blocks for direct simple shear tests (3 from each depth).

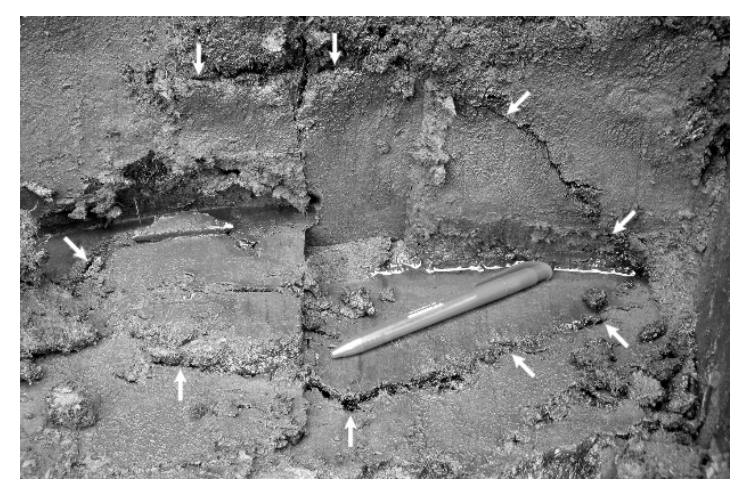

Figure 6. An example of a structural weakness within a peat mass identical to features found at Croaghan (for scale, the pen is $\sim 140 \mathrm{~mm}$ long). The pen is lying on a horizontal step, in front of a vertical face, cut into the lower peat for the purpose of extracting intact block samples. The white arrows identify a pre-existing crack, which formed a continuous irregular discontinuity inclined at approximately $45^{\circ}$ upwards away from the camera into the peat. The peat was weathered grey along the crack; in places semi-liquid peat slurry flowed out when intact peat was lifted clear of the crack. This example was at Slieve Rushen, Co. Cavan; those found at Croaghan could not be photographed because they were simultaneously discovered and destroyed by the sampling work. 
(A)

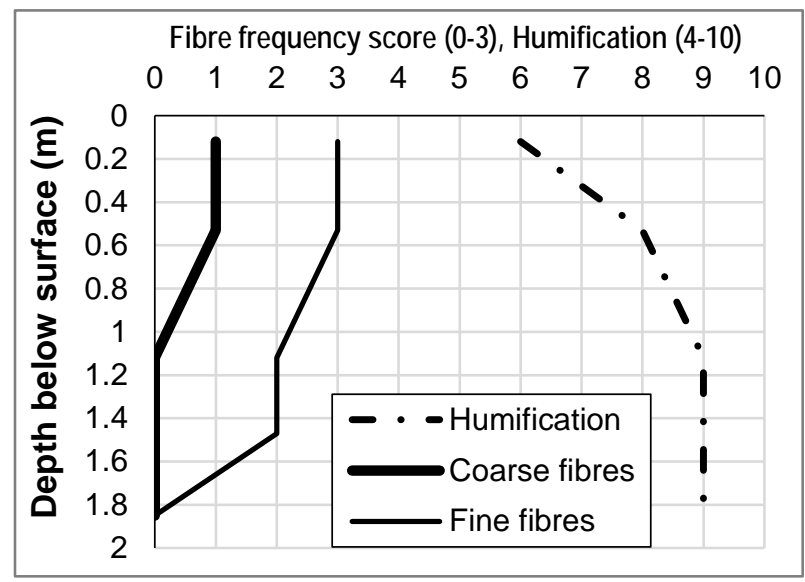

(B)

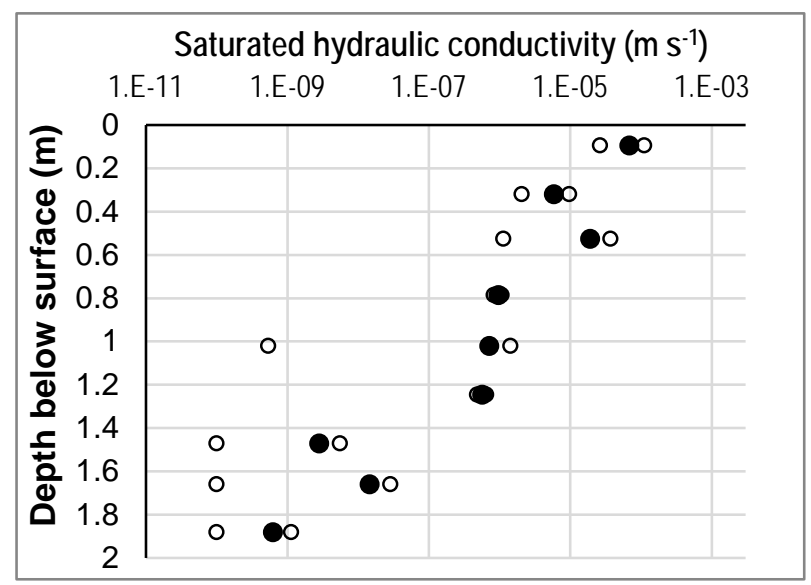

(C)

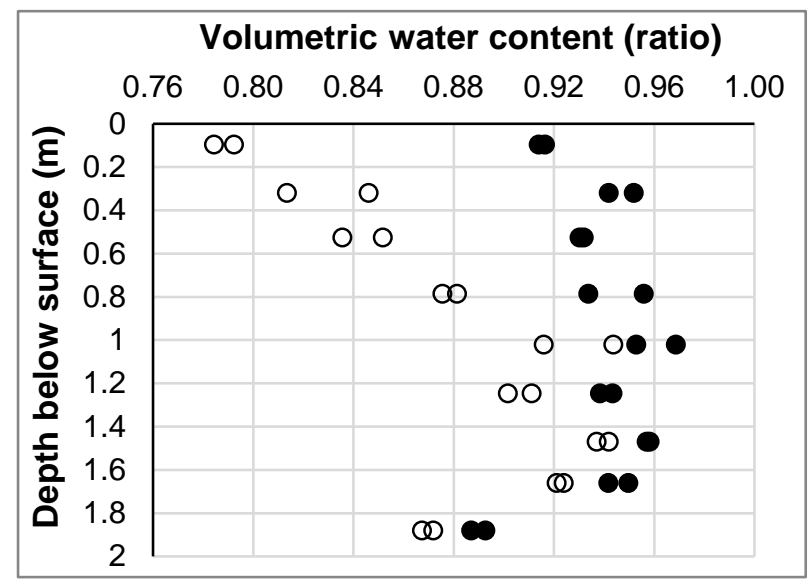

(D)

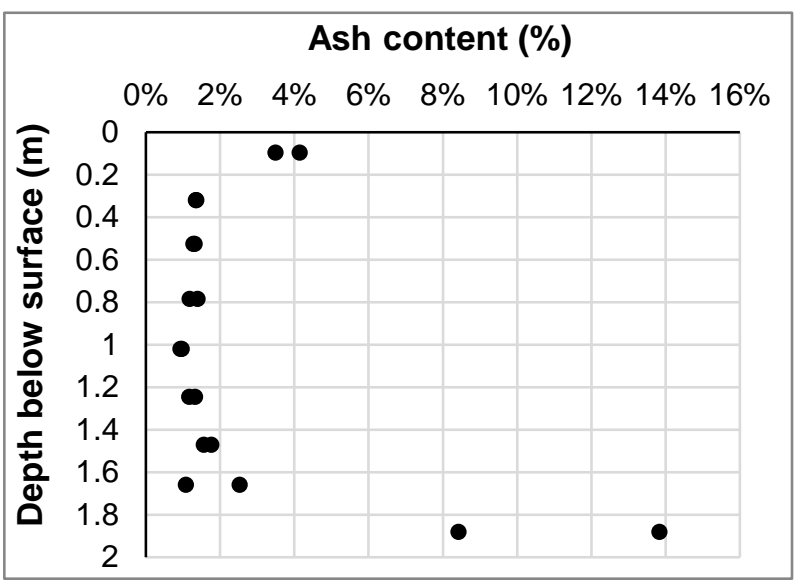


(E)

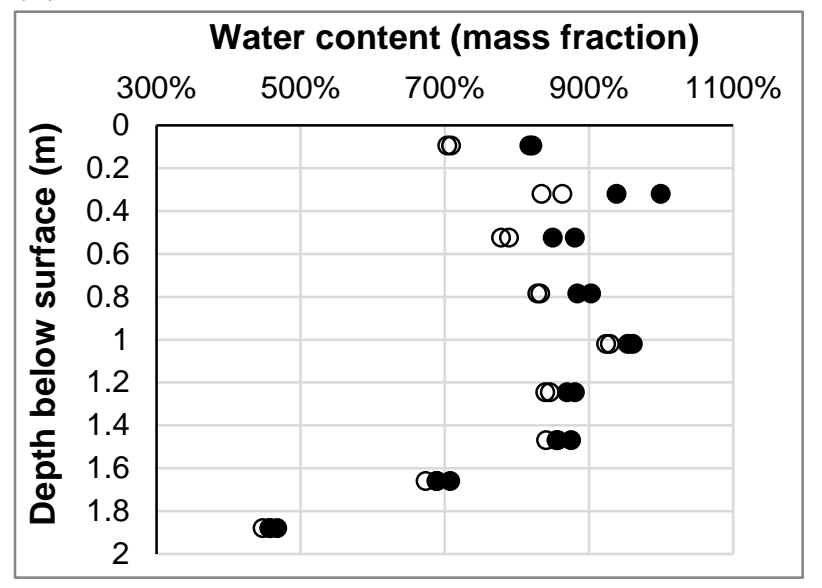

(F)

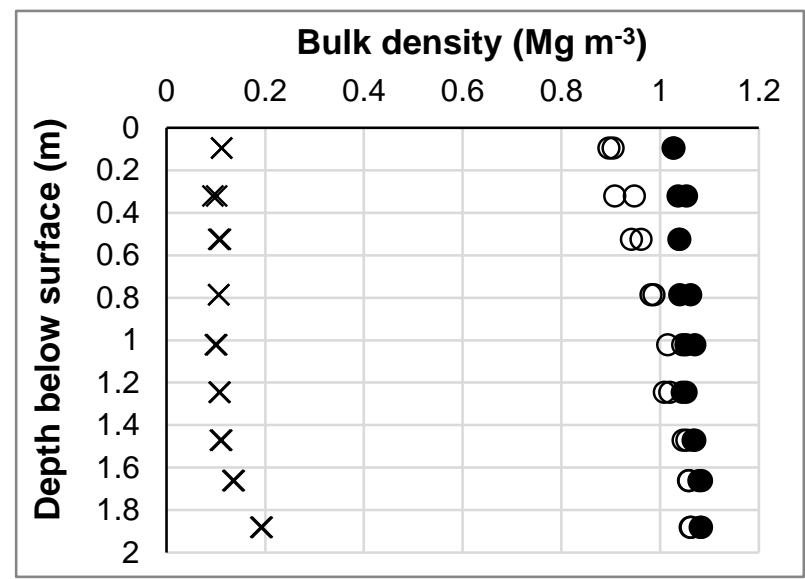

Figure 7. Depth variations of physical properties of peat. (A) Von Post fibre contents and degree of humification. (B) Saturated hydraulic conductivity: open circles = individual values for each depth; black circles $=$ mean value for each depth. (C) Volumetric water content: open circles = field-wet; black circles = saturated. (D) Ash content (1 - loss on ignition), showing individual data values. $(\mathrm{E})$ Mass fraction water content: open circles = field-wet; black circles = saturated. (F) Bulk density: crosses = dry; open circles = field wet; black circles = saturated.

(A)

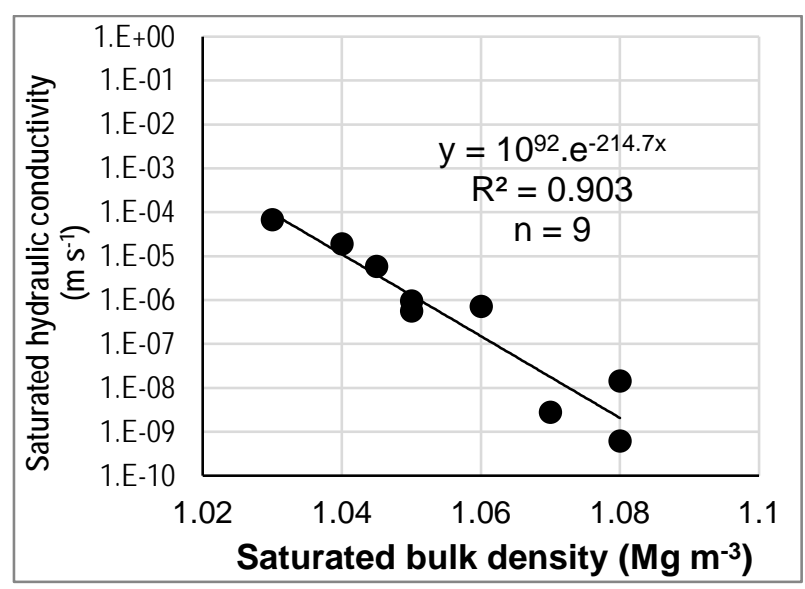

(B)

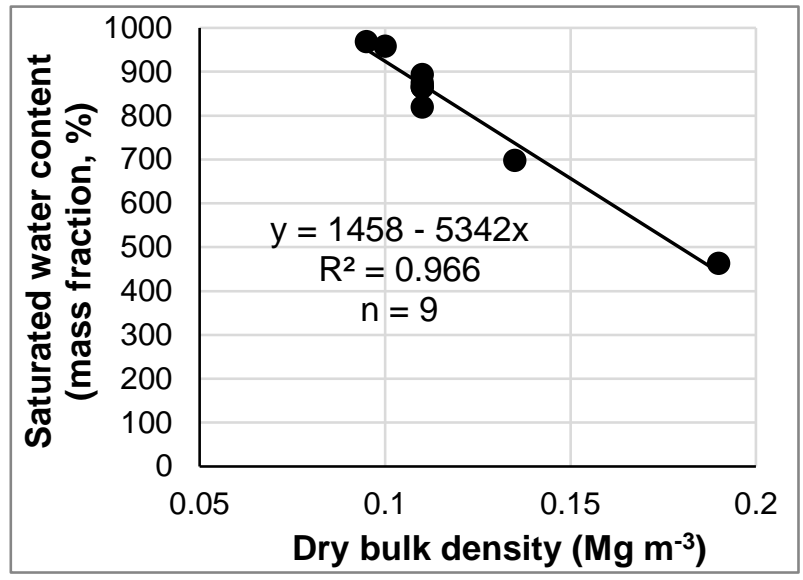

Figure 8. (A) Relationship between saturated hydraulic conductivity and saturated bulk density, based on the mean values of each variable for each depth. (B) Relationship between saturated water content and dry bulk density, based on the mean values of each variable for each depth. 
(A)

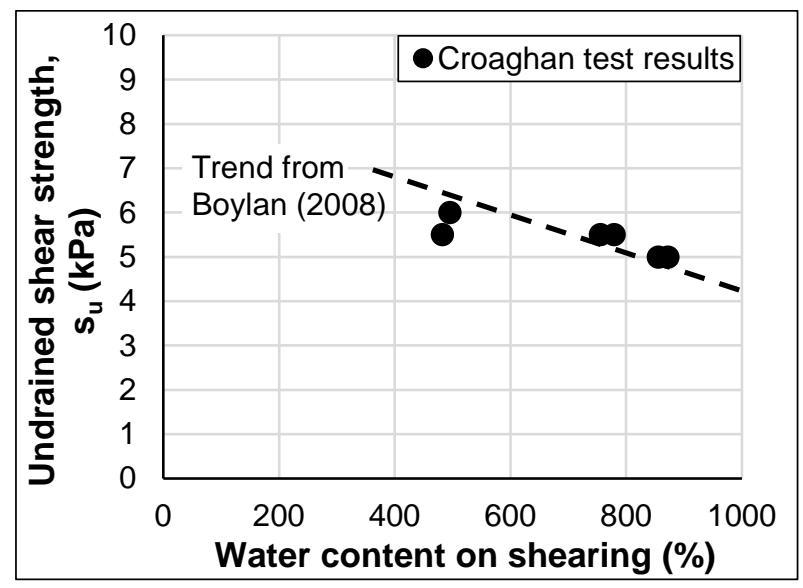

(B)

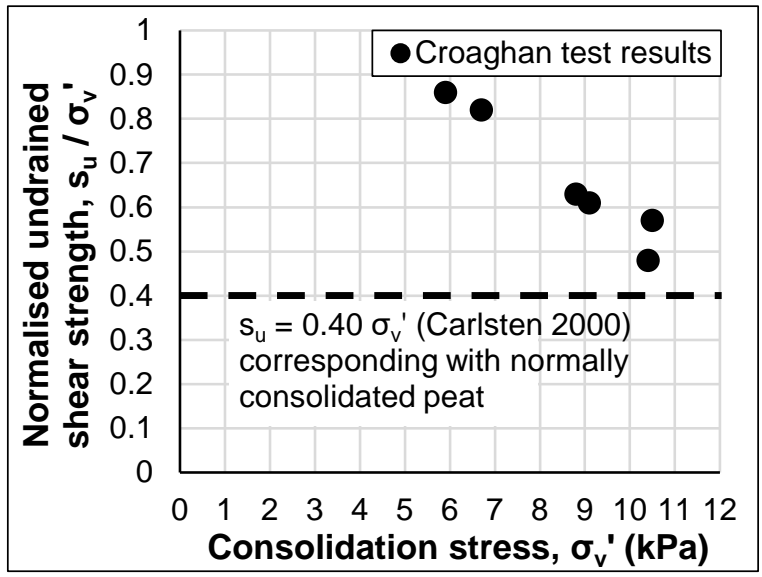

Figure 9. Results from the six Direct Simple Shear (DSS) tests. (A) Undrained shear strength, $\mathrm{s}_{\mathrm{u}}$, versus water content on shearing. (B) Normalised undrained shear strength, $\mathrm{s}_{\mathrm{u}} / \sigma_{\mathrm{v}}$, versus vertical consolidation stress, $\sigma_{\mathrm{v}}$ '.

(A)

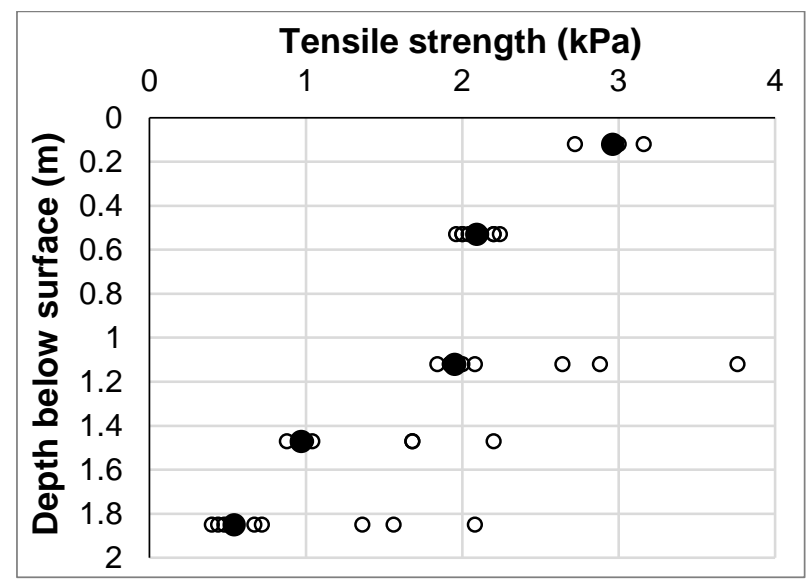

(B)

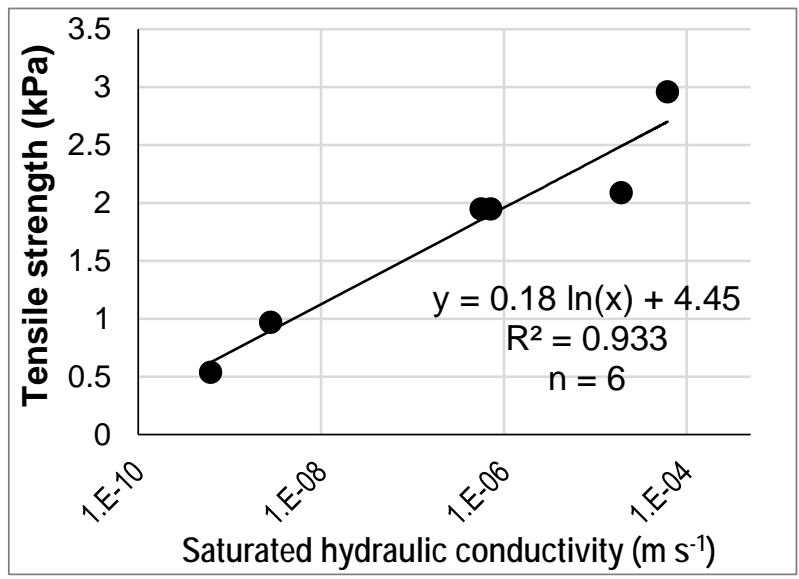

Figure 10. (A) Variations in tensile strength (TS) with depth: open circles = individual values for each depth; black circles = mean value for each depth (main cluster of results only). (B) Correlation between tensile strength and saturated hydraulic conductivity $\left(\mathrm{K}_{\mathrm{sat}}\right)$, based on the mean values of each variable for each depth (except TS value for $1.12 \mathrm{~m}$ depth plotted against $\mathrm{K}_{\text {sat }}$ values for $1.02 \mathrm{~m}$ and $1.245 \mathrm{~m}$ depth). 